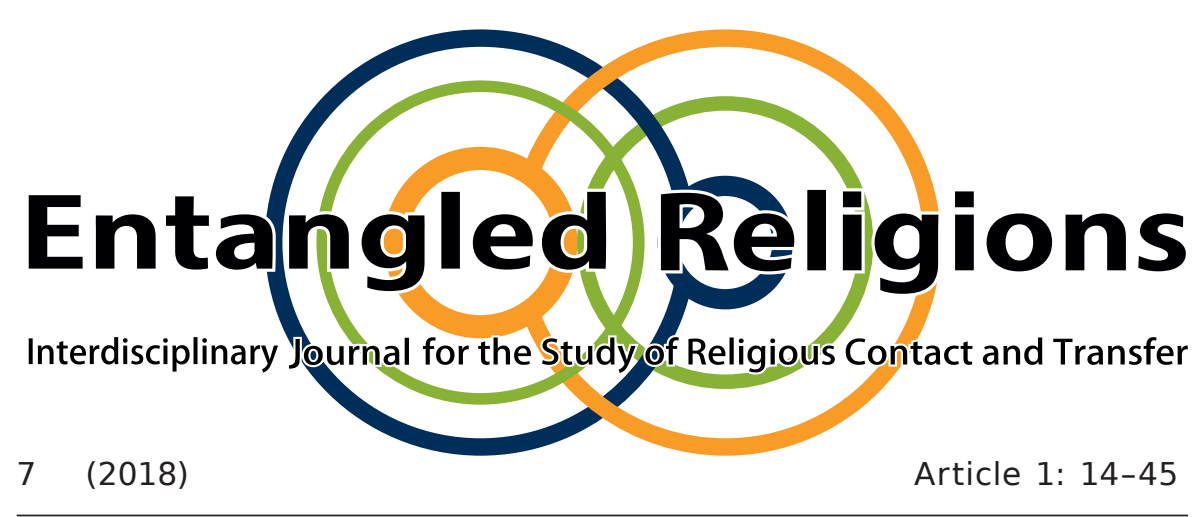

\title{
Sacred Space and "True Religion": The Irish Reformation and the Collegiate Church of St Nicholas, Galway
}

\section{STEVEN G. ELLIS}

School of Humanities, NUI Galway, Ireland

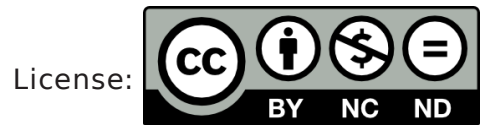

This contribution to Entangled Religions is published under the Creative Commons Attribution-NonCommercial-NoDerivatives 4.0 International Public License (CC BY-NC-ND 4.0 International). The license can be accessed at http://creativecommons.org/licenses/ by-nc-nd/4.0/ or is available from Creative Commons, 559 Nathan Abbot Way, Stanford, California 94305, USA

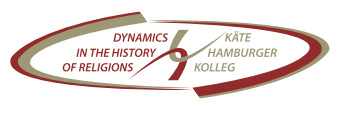

SPONSORED BY THE 


\title{
Sacred Space and "True Religion": The Irish Reformation and the Collegiate Church of St Nicholas, Galway
}

\author{
STEVEN G. ELLIS \\ NUI Galway
}

\begin{abstract}
This paper looks at the impact of religious reform in Tudor Galway, focusing on how the use of sacred space in the collegiate church of St Nicholas, Galway, was reshaped during the Reformation. The Elizabethan Settlement of Religion was, by European standards, quite conservative, permitting the retention of choral foundations and pipe organs and, in Ireland, even the traditional Latin offices, sung from the chancel. Unofficially, even some images and ornaments survived. Alongside these conservative survivals, the corporate worship of the new prayer book was also enhanced by regular sermons in English, Irish, and Latin by graduate preaching ministers, which were a popular innovation initially attracting large groups of people. Later, however, financial difficulties and the lack of a preaching minister for regular sermons undermined this local compromise: Galway merchants mostly drifted back to Catholic worship, which had remained freely available outside the town.
\end{abstract}

KEY WORDS Reformation; prayer book; common prayer; sermons; vicars choral

This paper looks at the organization and use of sacred space in one of the less successful theatres of the European Reformation, the Church of Ireland. Focusing chiefly on the impact of religious reform in the town of Galway, the paper assesses how the internal appearance and furnishings of Irish churches changed at this time, indicating a reformation of the idea of the church as sacred space. How sacred space was organized and used across Reformation Europe is a subject which has, until recently, attracted relatively little attention, despite the possibilities of this approach. It is also a subject which demands different sources from those traditionally used for the history of religious ideas, using churchwardens' accounts, 
parish registers, wills, and court records, in particular, as well as the visual and structural evidence provided by archaeology, art history, and architecture (see especially Coster and Spicer 2005, 2-3). To date, however, the concept of sacred space during the Irish Reformation has hardly been considered, perhaps in part because these types of sources are thought not to be available in any quantity to show how churches and cathedrals were adapted for worship across the Church of Ireland. ${ }^{1}$ Certainly, aspects of this topic will necessarily remain somewhat obscure in default of fuller records, with many of the changes, and also their precise chronology, remaining largely conjectural. As the following account focusing on the Collegiate church of St Nicholas, Galway, will demonstrate, however, it is nonetheless possible, in some cases, to offer rather more than a sketch of this topic, fleshed out in part from the experience of Tudor reform elsewhere, both from the better-documented Church of England, but also from the scanty surviving records from other parts of Ireland. ${ }^{2}$

\section{The Medieval Church and the Onset of Reform}

The remodelling of Irish churches to meet the demands of Protestant reform broadly followed European lines. As elsewhere, reform involved a radical transformation of sacred space to accommodate the religion of the

1 There is, for instance, only one surviving set of churchwardens' accounts for an Irish parish for the Reformation period (Empey 2009).

2 The surviving records relating to Christ Church cathedral, Dublin, would almost certainly allow a more detailed account of the remodelling of sacred space there than has yet been attempted. See especially Gillespie 1996; Gillespie 1997a; Milne 2000; Murray 2009. More generally, see also Gillespie 1997b; Lyttleton 2008, 80-104. 
Word, with its markedly different, biblio-centric presentation of Christianity, in place of the more visual focus and traditional ceremonies of the preReformation church. The major steps of this magisterial Reformation also followed-albeit with some delay-broadly along English lines. In brief, the characteristically Anglican contribution to the Reformation, the royal supremacy, was first enacted by the Irish parliament in 1536, with some common prayers in English introduced shortly thereafter. The first English prayer book followed in 1549, with further doctrinal changes following along more continental lines until the death of Edward VI in 1553. Finally, after a short-lived Catholic reaction under Mary, the Irish parliament reenacted the royal supremacy in 1560 , followed by a revised prayer book and royal injunctions, and a confessional statement, the Twelve Articles, in 1567 (Jefferies 2010; Ford 1995, 57). Remarkably, the cornerstone of this Elizabethan Settlement, the Book of Common Prayer, has survived with relatively minor changes down to the present. The Church of Ireland, which this legislation established, was by no means a straight copy of its English counterpart, and the political and cultural context in which it operated was very different; but even so, the resemblances were also very apparent.

The Collegiate Church of St Nicholas is the largest medieval parish church in Ireland still in constant use. It was built about 1320 by the wealthy merchants of the important seaport town of Galway, then an isolated English colony on Ireland's western seaboard, and it is dedicated to St Nicholas of Myra, patron saint of sailors. In 1484, the archbishop of Tuam released the town from his jurisdiction, erecting St Nicholas's church into a Collegiate church, governed by a warden and eight vicars appointed by the mayor and corporation. The town then successfully petitioned Pope Innocent VIII for confirmation of this grant, the townsmen representing themselves as a "modest and civil people" surrounded by savages raised in woods and mountains, unpolished and illiterate, who disturbed the townsmen in the 
exercise of their religious duties according to the English rite and custom. ${ }^{3}$ In 1551, these privileges were confirmed to the warden and vicars by royal charter. As Supreme Head of the Church of England and Ireland, King Edward VI also restyled the church as the King's College of Galway, and for the augmentation of divine service there, he granted them the profits of certain rectories, vicarages, and dissolved monasteries on the outskirts of Galway (for the 1551 charter, see Hardiman 1820, 240, appendices III and IV, vi-xxix; English translation in Berry 1989, 97-107).

During the Reformation period, the sense of civic pride in the church was also registered by various rebuilding projects, which resulted in its considerable enlargement. This involved the widening of the aisles to the north and south of the nave, and the extension of the south transept. The south aisle was enlarged between 1508 and 1535 (Fig. 14), while the enlargement of the north aisle was completed in two stages. The north part, as far as the chapel of the Blessed Sacrament (Fig. 2), was built in 1538, the chapel itself being erected sometime between 1538 and 1561, and the rest of the north aisle was finished by 1583 . The south transept was also extended by Nicholas Lynch FitzStephen when he was mayor in 1561 (Fig. 3), making it twenty-six feet longer than the north transept (Leask 1936, 2-23). By 1583, therefore, all the main structural changes to the church as it is today had been completed. Moreover, quite exceptionally for a Tudor parish church, these extensive alterations were also being undertaken at almost the same time as the introduction of the radical liturgical changes

3 The charter of the archbishop of Tuam, exempting the town from his jurisdiction, and the papal bull confirming this, are printed in Hardiman 1820, appendices I and II, pp i-vi. Throughout the sixteenth century, the warden was elected annually by the mayor and council; the eight vicars held office during good behaviour, and there was also a clerk and a sexton, plus four boys to assist the singing of the offices daily, all subject to the correction of the mayor and council (cf. Berry 1989, 19-22, 32, 35-6, 42). All photographs have been taken by the author. 
associated with the Reformation, although they probably had little to do with it.

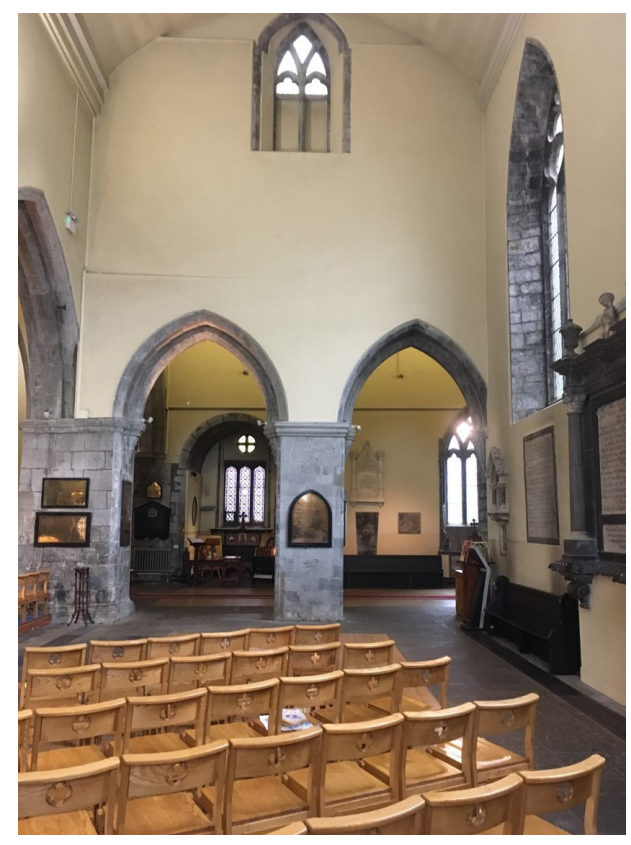

FIGURE 1
South aisle of the Collegiate church, looking towards the Chapel.

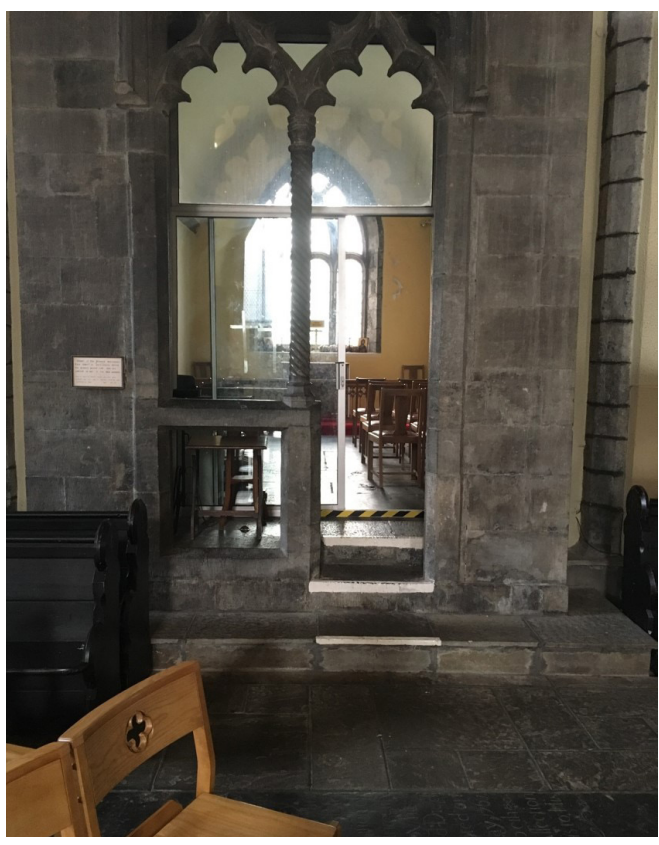

FIGURE 2 View into the Chapel of the Blessed Sacrament from the nave.

\section{The Elizabethan Settlement of Religion}

In 1560, the introduction of prayer book services as authorized by the Book of Common Prayer prompted a radical reordering of "the scenic apparatus of divine worship". ${ }^{5}$ Out went Mass, a Eucharistic liturgy said or sung in Latin by the priest apart in the chancel (Fig. 4), separated by a rood screen from the nave where the congregation stood or knelt as passive observers.

5 The phrase originated in Bishop John Jewel's letter to Peter Martyr, 1559 (Robinson 1842, 23). 
In its place came prayer book services in English, with a liturgy emphasizing "common prayer", interspersed with scriptural readings, and, on Sundays and holy days, including a homily or sermon. Priest and people worshipped together, with the congregation now expected both to understand and to participate.

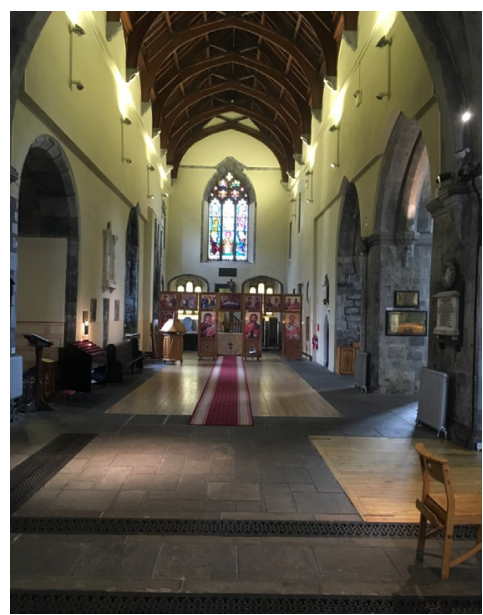

FIGURE 3

View of the
south transept,
with ikons of
the Romanian
Orthodox
church.

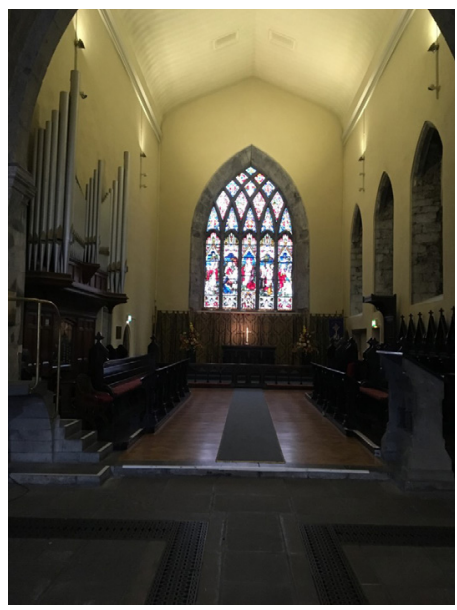

FIGURE 4

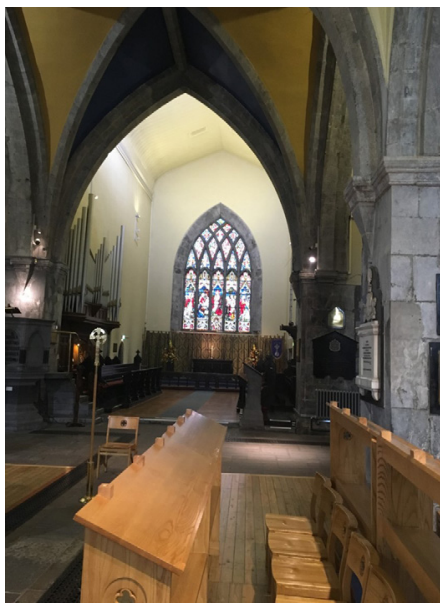

FIGURE 5

Chancel with high altar and choir stalls.

In regard to these new services, the rubrics of the Elizabethan prayer book provided that common prayer "shall be used in the accustomed place of the church, chapel, or chancel" (Booty 2009, 48). No doubt in Galway this often meant in the nave, with a reading desk positioned just outside the chancel for the minister to read the service. The enhanced status of the offices, or common prayer, in public worship was also underlined by a revised clause in the preface to the Book of Common Prayer which explained that, while priests and deacons should daily say Morning and Evening Prayer either privately or openly, "the curate that ministreth in every parish church or chapel ... shall say the same ... where he ministreth, 
and shall toll a bell thereto, a convenient time before he begin, that such as be disposed may come to hear God's word, and to pray with him" (Booty 2009, 17). Weekday services for small congregations could also be accommodated in one of the side chapels.

In addition, two special provisions of the settlement which were relevant to prayer book services in Galway also had an impact on what may be described as the soundscape of the Reformation, ensuring an important continuing role for the organ, bells, and choristers in the post-Reformation Irish church. First, the Elizabethan injunctions included a clause permitting the common prayers in "a modest and distinct song ... that the same may be as plainly understanded, as if it were read without singing"-in other words, singing in Reformation style (Frere and Kennedy 1910, iii, 23). ${ }^{6}$ The clause was particularly aimed at the cathedrals. The Tudor Reformation retained these choral foundations, with pipe-organs and a large staff of clergy, which had no parallel elsewhere in Protestant Europe; but this choral exploitation of the prayer book also extended to collegiate churches such as Galway, where vicars choral had also been retained. Mayor Lynch had also provided the church with "an organ and great bell" in 1561 (Leask 1936, 9; cf. O'Sullivan 1942, 77; Yates 2008, 72). The erection of a belfry in the tower followed in 1590, a chime of new bells being provided to summon the town for communal worship, perhaps to still toll a solemn funeral knell, and no doubt also to alert the townsmen in case of a possible attack (Hardiman 1820, 243). ${ }^{7}$ The choir continued to sing the services daily, and no doubt continued to use the chancel for sung services (Fig. 5).

6 For the impact of the Reformation on the soundscape of churches, see Smith 2004 (esp. part II on early modern England); McDermott 2012, 177-198.

7 According to the Elizabethan Injunctions, however, only "one bell was at convenient time to be rung or knolled before the sermon": Frere and Kennedy 1910, iii, 15. One of this chime of bells still survives in the church. 
A reference to the boys in the 1580s shows that the choir was still assisted by four poor boys supported by the church as choristers and trained by the clerk (Hardiman 1820, 243; Berry 1989, 20, 36; MacLysaght and Berry 1944, 15). By contrast, parish churches elsewhere heard very little music at all after the Reformation beyond the congregationally sung metrical psalms (cf. MacCulloch 2005, 90-92; Whiting 2010, ch. 11; Heal 2003, 298-302).

Also very relevant in shaping the services in Galway was a special clause inserted into the Act of Uniformity as it applied in Ireland, which provided that "in every such church or place where the common minister or priest had not the use or knowledge of the English tongue, he might say or use ... common and open prayer in the Latin tongue", as prescribed in the Liber precum publicarum (Statute, 2 Elizabeth c.2: Butler 1786-1801, i, 284-90). In England, the Liber precum publicarum had been published for use in college chapels and collegiate churches, as indeed Galway was (cf. Haugaard 1968, 113-17). In Ireland, however, rather than providing an Irish translation of the prayer book, which would have undermined the government's anglicizing strategy, its use was greatly extended. Formally, the Liber precum publicarum was a Latin translation of the English prayer book, but the latter was, in turn, mostly an English translation of the preReformation Sarum Use. In effect, therefore, this clause waived the almost universal insistence on the use of the vernacular in reformed churches by permitting the more general use of this Latin prayer book in Ireland. ${ }^{8}$

8 Even in parts of the English Pale, the slack enforcement of the Irish Uniformity clause permitted the public use of the Liber precum publicarum instead of the English prayer book (Murray 2009, 257, 277-8). 


\section{Sacred Space and the Reformation}

Galway was supposedly an English outpost, but in both 1551 and 1615 over half the vicars were "mere Irish" and might plausibly have claimed ignorance of English (Hardiman 1820, app. iv; Berry 1989, 101; Leslie with Crooks 2008, 81). Even the chapels of Moycullen, Oranmore, and Roscam, served by the College just outside the town, were in Irish-speaking districts, and here the offices were presumably said by the vicars in Latin. At any rate, the effect of these two provisions in the settlement was to create an anomaly in Galway whereby, for some time after the Reformation, the soundscape of the Collegiate church remained largely unaltered. The traditional offices continued to be sung in Latin from the chancel by vicars choral in the choir-and no doubt to traditional settings, too-thus reinforcing the impression of continuity with the Catholic tradition.

In place of the Mass, however, the celebration of Holy Communion became an occasional aspect of prayer book services after the Reformation, mainly on major feast days. Probably its frequency in Galway lay somewhere between practice in Christ Church Cathedral, Dublin, where Communion was celebrated on a monthly basis, and in St Werburgh's parish there, for which Ireland's sole surviving set of churchwardens accounts suggest that Communion was celebrated only at Easter, and possibly also Whitsun (Gillespie 2000, 177). Paradoxically, however, the infrequency of lay Communion reflected pre-Reformation practice, when the laity had been "shriven and houseled" just once annually, at Easter. The reformers later complained that many of those who resorted to church would not receive Communion, ${ }^{9}$ but reluctant conformists found it fairly easy to frustrate the

9 On the reluctance to receive Communion, see, for instance, Canny 1979, 431, 433, 443, 445. 
reformers' original intention for frequent lay Communion. The prayer book rubrics required those who "intend to be partakers of the Holy Communion" to "signify their names to the curate overnight ... or immediately after" (Booty 2009, 247) Morning Prayer, also specifying that "there shall be no celebration of the Lord's Supper ... except four, or three at the least, communicate with the priest" (267). Otherwise, the priest was to say "all that is appointed at the Communion" as far as the prayer for the church militant, and then add one or two collects, a practice later known as the Ante-Communion (266-267).

In terms of the use and appearance of the chancel, however, the infrequency of Communion again tended to obscure the differences between pre-Reformation practice and prayer book services. During the Communion, the Lord's Table was to be moved so as to stand "in so good sort within the chancel, as whereby the minister may be more conveniently heard", with "the priest standing at the north side of the Table"; at other times, "the holy table" was to be "set in the place where the altar stood", that is, against the chancel's east wall, leaving the chancel largely free, as before, for the vicars choral in the choir (Frere and Kennedy 1910, iii, 27-8). ${ }^{10}$ By contrast, during his travels through Ireland in 1635, Sir William Brereton noted that in St Peter's, Drogheda, where the Primate, Dr. James Usher, preached every Sunday morning when in residence, "the communion table is placed lengthwise in the aisle" in "the body of the church", which was "kept in good repair", "over against the pulpit"; but "the chancel, as no use is made of it, so it is wholly neglected and in no good repair" (Brereton 1844, 135). The prayer book rubrics had ordered that "the chancels shall remain as they have done in times past", but since

10 The injunctions amended the prayer book rubric that the holy table was to stand in "the body of the church, or in the chancel, where Morning Prayer and Evening Prayer be appointed to be said" (Booty 2009, 248). 
they were now seldomly used in parish churches, they were frequently neglected, like St Peter's (Booty 2009, 48). ${ }^{11}$ Post-Reformation churches in poor rural parishes were, in any case, often simple oblong buildings, lacking a structural chancel despite the conceptual division between nave and chancel (Lyttleton 2008, 82). Responsibility for the chancel's maintenance normally fell on the incumbent, and so the little-used chancels suffered severely in the dilapidations which followed the Reformation. In 1576, the bishop of Meath and Clonmacnois reported that, among the 224 parish churches of his diocese, there were "very fewe chauncells couered" (The National Archives [TNA], SP 63/55, f. 129).

In other respects, the adaptation for prayer book worship of the Collegiate church focused more on the removal or downgrading of traditional furnishings. Indeed, the progress of the Reformation in Ireland was characterised by periodic campaigns of iconoclasm and purges of church space, extending through much of the seventeenth century. Little is known about the precise chronology of Tudor reform in Galway, but in Dublin, within weeks of the legislation being passed by parliament in 1560, orders went out to "newe paynt the walls of Christ Church and St Patricks and in sted of pictures \& Popish fancies to place passages or texts of Scripture on the walls" (White 1941, 235). The most prominent feature of traditional church furnishings was the rood loft and screen before the chancel. In Galway, even the screen was removed. In Christ Church Cathedral, Dublin, the rood screen itself survived, but the rood and figures of Christ, Our Lady, and St John had been removed by 1564, when "all the peyntyd bords that was in the great arche oure the rode, wher the story of the passion was peyntyd" were taken down. Instead, the

11 Brereton was more interested in the provision of sermons, but he occasionally remarked on the use of sacred space in churches. 
workmen put up new boards in the arch (Gillespie 1996, 38-9). Sir William Brereton noted in 1635 that "only the chancel is made use of, not the body of the church", but that "the chancel is but plain and ordinarily kept". He thought, by contrast, that Dublin's second cathedral, St Patrick's, was “in best repair and most neatly whited and kept of any church I have seen in Scotland or Ireland, and especially in the chancel, wherein it is curiously and very artificially arched and whited overhead" (Brereton 1844, 138). This arch was normally the location for the only picture not to attract official disapproval, a set of the royal arms of the queen. In St. Werburgh's parish, Dublin, the churchwarden's accounts included an entry in 1592 for the cost of painting the queen's arms and the Ten Commandments (Empey 2009, 132; cf. MacCulloch 1999, 161). These must also have figured in Galway, the Ten Commandments usually being displayed on boards on the east wall of the chancel (MacCulloch 1999, 158; Yates 2008, 73).

At the same time as the rood loft and figures disappeared, the effigies of the saints and other "graven images" were also removed-as likely to confuse the ignorant and lead people into idolatry. In Galway, some images and ornaments which were allegedly the subject of popular abuse had already been removed when Lord Deputy Grey visited the town in 1538 (McNeill 1922, 11-37 [which prints William Brabazon's “account of jewels, ornaments, crosses and images confiscated"]; Hardiman 1820, 239; cf. Bradshaw 1974, 103-4). Fearing further spoliation, the churchwardens made an agreement with James Lynch, merchant of Galway, in 1546, whereby he received "the juelles of ye chyrche"-its "grete crose of shylver", four silver candlesticks (two bracket, two freestanding), a pyx for the sacrament, and four silver chalices-in pledge for $f 60$ sterling outlaid by him for a lectern of brass, candlesticks and wax, plus glass, lead, and bricks for repairs to the church (O'Flaherty 1846, 230). Some of these jewels would have been subject to confiscation during the short-lived Edwardian Reformation 
anyway, but two silver pyxes, retained initially by the College for, most probably, use as communion cups, were purloined sometime after 1576 by the bishop of Elphin, John Lynch, when he was warden (Hardiman 1820, 243). ${ }^{12}$ As for any remaining images, these should all have been removed in 1560 in line with the Queen's Injunctions, but clearly they weren't. On their first circuit through Connaught in late 1569, Lord President Fitton and the council found the clergy and people generally "very cold in religion \& to muche enclyned to suppersticion". Thus, both in Galway and elsewhere, they "viseted sundry \& many of $\mathrm{y}^{r}$ ydolls and ymages in ther churchez \& comytted them to the ffyer", also reforming "the churche of Galway" in particular "in sondry other necessary articlez according to the quenz iniunconz" (TNA, SP 63/30, no. 4, f. 9r-v. See also Canny 1976, 111).

Despite this, a few instances of decorative carvings attached to walls, pillars, and tombs survived this purge in the Collegiate church. The angel high in the archway at the junction between the south aisle and south transept (Fig. 6) is now the only angel to have survived unscathed, but others escaped the earlier Tudor purges, only to be decapitated in the iconoclasm by the Cromwellian army in $1652 .{ }^{13}$ A surviving wall tomb (Fig. 7) in the south transept includes a carving, also now defaced, of a crowned figure of Christ with upraised hands and open robe showing his five wounds (Higgins and Heringklee 1991, 214-17; Fig. 8). The Lynch window and another altar tomb with a carving of an angel, also now defaced, is also

12 In England, Elizabeth's bishops increasingly insisted on parishes purchasing a specially designed communion cup for the wine now received by the laity at communion, but initially, in 1559, a traditional chalice, or sometimes a pyx, was used (Whiting 2010, 63$6)$.

13 Galway was surrendered to the Cromwellian army in 1652 after a nine-month siege, and the Collegiate church was then converted into a stable. It is thought that the defacement of the remaining decorative carvings took place during the Cromwellian occupation (Berry 1989, 37-8). 
found in the south transept (Fig. 9); and up high in the north transept is a corbel with a Tudor carving, apparently of a Biblical Joshua holding two bunches of grapes (Fig. 10). Some traces of dark paint survive on some of these carvings, which, when first erected, would have been elaborately painted.

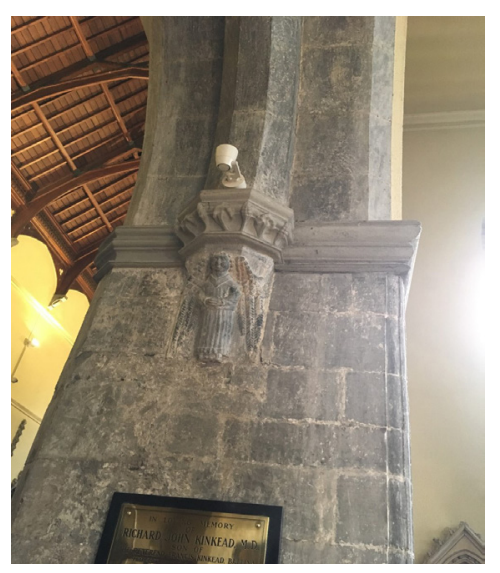

FIGURE 6

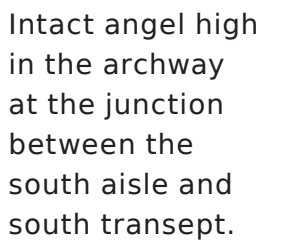

Intact angel high in the archway between the south transept.
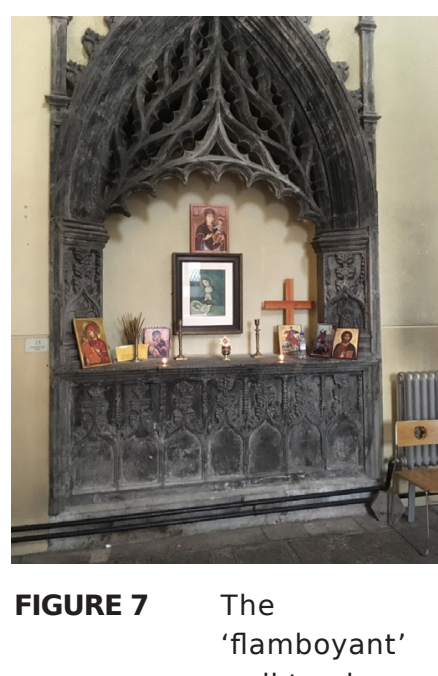
wall tomb in the south transept.

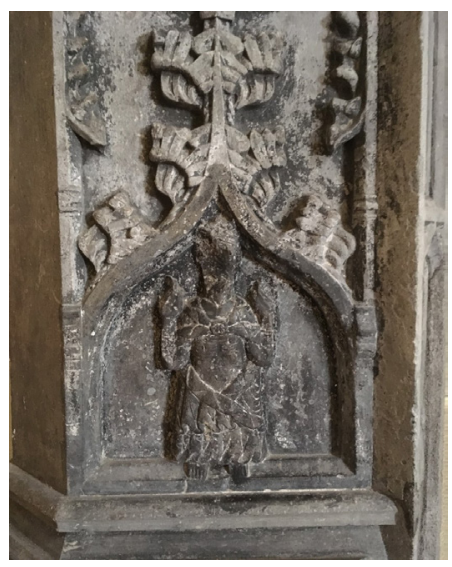

FIGURE 8

Detail showing the five wounds of Christ on the 'flamboyant' wall tomb.

In place of ornaments and images, the church was to purchase both a poor box and a copy of "the whole Bible of the largest volume in English ... and the same set up in some convenient place" (Frere and Kennedy 1910, iii, 10, 16-17) in the church, perhaps on the brass lectern acquired in 1546. In Dublin, two large bibles were set up in the cathedrals "for the instruction of those whoe pleased to hear them read" (White 1941, 235). The poor box was an official reminder that charity should be directed to needy people made in God's image in place of offerings to graven images. The money collected from fraternities and guilds attached to the church's now redundant side chapels (discussed below) was also to be placed in the poor box. These days, the one item of church furnishing from the late Tudor 
period which remains in regular use is the beautifully carved baptismal font located at the back of the south aisle between the west door and the south porch (Fig. 11). In England, canon 81 of 1604 ordered the provision of a stone font for baptism, and Galway's font must have been provided about the same time (Yates 2008, 73).

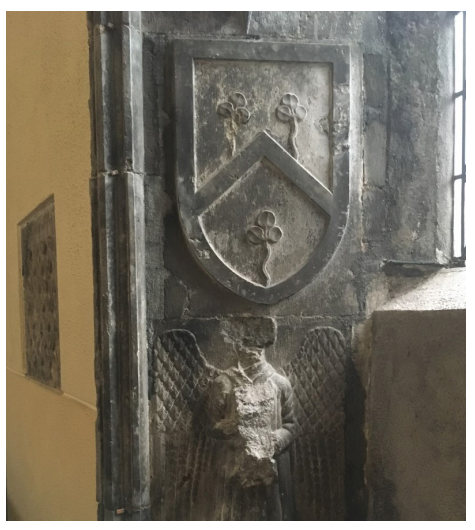

FIGURE 9
The Lynch window and altar tomb, with the carving of an angel, now defaced, in the south transept.

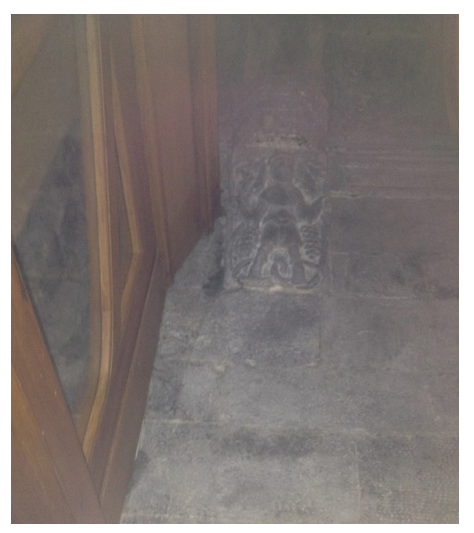

FIGURE 10 Corbel in the north transept, a biblical Joshua with a bunch of grapes.

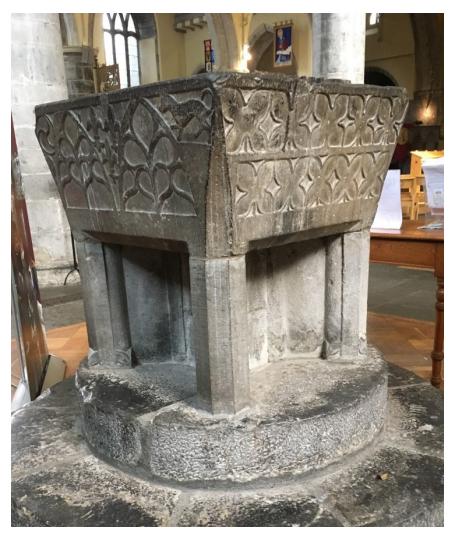

FIGURE 11 The stone baptismal font towards the rear of the south transept, between the west door and the south porch.

Another prominent feature of medieval churches which fell into disapproval during the Tudor reform were the various side chapels with their altars. The Collegiate church once had no less than thirteen of these, but only two enjoyed an attenuated existence into modern times (Fig. 12). The chapel of Christ holds the oldest tomb in the church, known as the Crusader's tomb. The most recent, the chapel of the Blessed Sacrament built between 1538 and 1561, attests to the popularity of traditional belief in the Real Presence on the eve of the Reformation, at just that time when the Eucharistic doctrine, which its name implies, fell under 


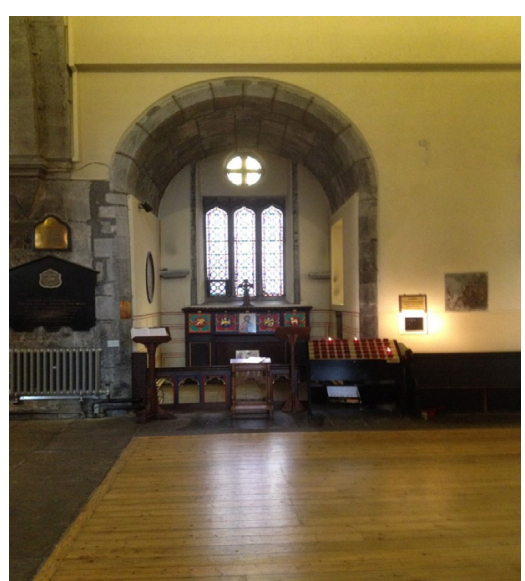

FIGURE 12 The Chapel of Christ, in the south transept.

disapproval (Hardiman 1820, 246; Leask 1936, 2-23). Assuming it once housed the reserved sacrament, its originally intended use must have been short-lived. Also of early Tudor date is the holy water stoup now in the north aisle (Fig. 13). Although likewise soon redundant in its original role, it is of a rare and costly freestanding type, which presumably explains its survival. ${ }^{14}$ Given the expense of providing a replacement if, as was widely expected, Catholicism should be restored, even bulky "monuments of superstition" were

illicitly dismantled and buried rather than destroyed. In Kilkenny, for instance, when Queen Mary's proclamation permitting the celebration of Mass reached the town in summer 1553, the cathedral clergy of St Canice's "suddenly set up all the altars and images in the cathedral church" during a short absence by their fervently Protestant bishop, John Bale. Earlier, they had likewise "brought fourth their copes, candelstickes, holy waterstocke, crosse and sensers [and] mustered fourth in generall procession" chanting the old Latin Litany (Parke 1810, 452.

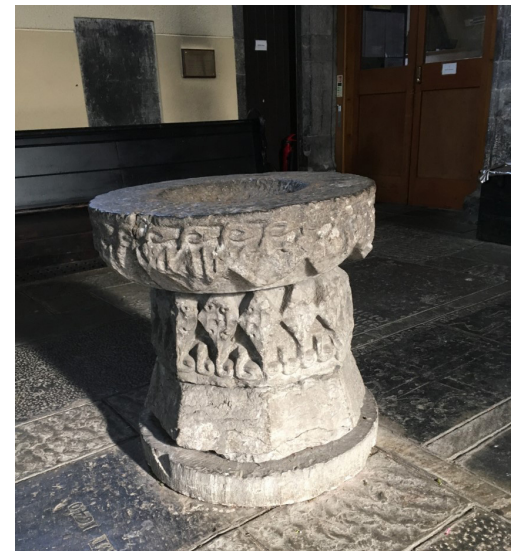
Cf. Ellis 1984, 290).

FIGURE 13 stoup, north transept.

14 The Collegiate church's holy water stoup was eventually converted into a flower pot in a lady's garden, from which it was rescued by the rector in Victorian times. 
In Galway, when Sir Henry Sidney first visited the town as lord deputy in April 1567, the liturgy, furnishings, and ornaments of the Collegiate church were in the throes of transition to prayer book worship, but there was still visible continuity with traditional forms. Sidney was received by the mayor and aldermen on arrival, but he then "wente vnto the churche and in the churche yarde the bishop [Christopher Bodkin, archbishop of Tuam] received hime in his powntiffisaylles acompenid withe dyveres prestes and clarkes in copes singing". Thereafter Sidney "enterid the churche of our ladye" just outside the town "and theare remained vntill tedium [Te Deum] was sowng in Laitin, and after prayares he wente to his loginge" (Trinity College Dublin [TCD], MS 581, f. 96v; Collins 1746, i, 28; as cited in Ronan 1930, 224).

\section{Word and Sacrament in Elizabethan Galway}

What Sidney had encountered at the Galway churches was hardly what had been envisaged by the Elizabethan Settlement; but it broadly accorded with the law, which permitted the singing of what were in effect the traditional Latin offices-in this case, Matins with Te Deum laudamusin what was supposedly a reformed setting. Archbishop Bodkin, a known conservative, had nonetheless taken the Oath of Supremacy promptly in 1560. He was a native of Galway and later supported, with the revenues of some benefices in his diocese, the education of clerical students at Oxford (Nicholls 1970, 151-7; Digges LaTouche 1994, ii, no. 199; Hardiman 1820, 235). The Ornaments Rubric of the Elizabethan prayer book stated that "the minister at the time of the Communion, and at all other times in his ministration, shall use such ornaments in the church as were in use ... in the second year of the reign of King Edward the Sixth" [viz. 1548-49] (Booty 
2009, 48). In England, a compromise had in practice soon been worked out whereby priests wore copes for Communion and surplices at other services; but strictly, the rubric meant the continued use of traditional clerical vestments, which is what Sidney encountered; and with the continued use of the chancel for singing the offices in Latin, this also implied that the use of sacred space was unaltered (Haugaard 1968, 183-200, 205-15).

Lord Deputy Sidney had been much more impressed the following Sunday, when he attended the Collegiate church. He heard there

averye godly sarmound prechid by apriste of lerland wiche was swmtime a ffrieare. He made his preface in Latin and after deliuerid vnto the lorde deputie he declaride in Inglishe a verie godlye lesson to the comffowrte of a greate number that harde. The sarmound endid, the lorde deputie cawled ffor [the] said prechare in thawnking hyme ffor his good sarmound, promising hyme that he wold be his good lord and m[aste]r. (TCD, MS 581, f. $96 v$ )

The preacher was possibly Rowland Lynch, later bishop of Kilmacduagh, who was brought up by Francis Martin, from one of the town's oldest families and a mainstay of Protestantism there. Latin featured in the worship once again, which probably took the form of Morning Prayer, Litany, and AnteCommunion as one continuous rite, then the normal Sunday service (Ford 1997, 43; Yates 2008, 72). Had it been a Communion service, the liturgy of the Eucharist and the distribution of communion would have meant a long delay after the sermon, but once the sermon ended, Sidney called for the preacher.

For some time after 1560, therefore, despite changes in the liturgy and to ornaments and church furnishings, the sights and sounds of worship in the Collegiate church, and so the use of sacred space there, were 
perhaps closer to the Catholicism of Queen Mary's reign than what had been envisaged in the Elizabethan Settlement, at least until 1568, when there was a formal prohibition on the public celebration of Mass in Galway (Hardiman 1820, 85). In part, this was because most of the existing clergy had chosen to stay on following the Settlement, but the transition to prayer book worship also meant that they were, in effect, mostly downgraded to reading ministers who could not preach but only read the service. The warden at this time was Patrick Blake, who was the warden specified in Edward VI's charter of 1551. When he failed to appear before the queen's commissioners, however, he was arrested by the mayor and duly appeared before them in November 1563 at the archbishop of Armagh's residence at Termonfeckin. Presumably, he then took the oath of supremacy and satisfied the commissioners (MacLysaght and Berry 1944, 13; Hardiman 1820, 241).

Meanwhile, the College's possessions were gradually alienated by the warden and vicars to their friends and kin (MacLysaght and Berry 1944, 10, 13-14, 100; Hardiman 1820, 241-2). The College had earlier been endowed with eight rectories and vicarages, mostly in surrounding parishes in the Tuam diocese, plus the churches of three dissolved monasteries just outside the town walls. Their value was small, however: the vicarage of Kilcommon (Hollymount, Co. Mayo), for instance, was worth no more than ten shillings a year when assessed for First Fruits in 1585/86, although twenty years earlier it had been used to support Conla O Kennayn, then a student at Oxford. Most of these livings, in fact, were miserably poor and hardly provided an adequate income for the warden and eight vicars choral (Nicholls 1970, 153, 155; Hardiman 1820, 240; Valor beneficiorum 1741, 22 3). Once the College was in more reliable hands, however, Queen Elizabeth leased various dissolved abbeys, rectories, and tithes in Co. Galway to the College in 1578 to augment its income so that "the warden and vicars might 
better continue together" and maintain "a godly and learned preacher" among them (Digges LaTouche 1994, ii, no. 3466; Morrin 1862, 14). By then, the College's income amounted to around $£ 80$ a year, although the very least amount needed to maintain a graduate (i.e. preaching) minister was a benefice worth $£ 30$ a year (O'Flaherty 1846, 214 (prints the return for the College of Galway, Regal Visitation, 1615); Ellis 1990, 254). The wardenship's surviving records also show that the warden and vicars increasingly resorted to law under Elizabeth to protect income now being withheld from rents, vicarages, and also the offerings and dirges which were traditionally paid for commemorative Masses for deceased family members. Thus, even as its liturgy, ornaments, and church furnishings were gradually adapted to meet the demands of prayer book worship and theology, the collegiate church still clung to traditional sources of income underpinned by a supposedly outmoded theology. The College's finances continued to decline, eventually prompting the warden and vicars to lodge a lengthy petition to the mayor and corporation, around 1596, seeking to recover twenty-three separate amounts of income. These included dirges (items worth $£ 1$ 15s. 8d.), tithes (worth $£ 8$ 5s. 0d.), two vicarages ( $f 1$ 15s. $0 \mathrm{~d}$.), the provision of two salmon weekly, and offerings of $8 \mathrm{~d}$. each due from diverse persons at Christmas and Easter (MacLysaght and Berry 1944, 10 $18,100)$.

Nonetheless, by the time of Sidney's next visit to the Collegiate church, in 1576, a more consistent effort was being made to establish "true" religion in Galway, in particular through the regular provision of sermons. On the occasion of the earl of Clanrickard's sons submitting to the lord deputy, Sidney was again impressed by a sermon given by "a countryman of their own, called Lynch", who preached in Irish, English, and Latin. This was John Lynch, the recently appointed warden of the College (1576-83). He had been educated at Oxford in Mary's reign, and was "sometime a friar 
in Greenwich", but after reading Calvin's Institutes, he became "a reformed man, a good divine and preacher". Hearing good reports of "his sufficiency, endeavour and travail in preaching", Queen Elizabeth later appointed him bishop of Elphin (1583-1611) (Brady 2002, 88; Morrin 1862, 66; Ford 1997, 43).

The provision of regular sermons was one of the more popular innovations of prayer book worship, if not precluded by the shortage of graduate preaching ministers, which were then something of a rarity among Church of Ireland clergy. In Elizabeth's early years, the Collegiate church had clearly made a special effort on Sundays and holy days to include sermons rather than to fall back on readings from the Book of Homilies; and regular sermons were a major reason for the full attendance at services there. During the early 1570s, when Lord President Fitton was resident in Galway, "the mayor, his brethren \& many of the towne both men \& women more orderly repayred to church then in eny towne in Ireland"; and after Fitton's departure "the people contynewed their said goeng to church" by "the meanes of one Walton", a preaching minister who "came into Galwaye \& laye there" (TNA, SP 63/131, no. 64, f. 203). As the Jesuit missionary Fr. David Wolfe admitted, fifteen young men in the town had accepted reformed doctrines as early as 1574, and in 1577 another hostile source thought that Galway was the town "where dwell the greatest heretics of that realm" (Rigg 1916, 1926, ii, 161, 337). An inquiry was instituted in 1585 as to whether members of the corporation there abstained "from church to here God's dyvyne service, according to Her Majestie's proceedings" or whether they "do use any other servise prohibited by God and her majestie's lawes", but it supposedly found no evidence of this. The warden, vicars, and priests were, however, enjoined that they "do use only God's divine service daylie, according to her majestie's injunctions, and do there minister sacraments and sacramentalls accordinglie" (Hardiman 1820, 
243). Despite the implication that some aspects of traditional Catholic rites had hitherto survived illicitly, the orders suggest the use of the English prayer book, with Morning and Evening Prayer as the regular daily services. In 1586, Sir Richard Bingham, the president of Connaught, reported that the inhabitants of Galway were "for the moste parte, very well affected in religion alredy and more geven to ymbrase the doctrine off the Gospell generally then any people in Ireland" (TNA, SP 63/122, no. 45).

Regular sermons at prayer book services also presupposed both the provision of a pulpit at this time and congregational seating in the nave. Elizabeth's injunctions had stipulated "a comely and honest pulpit ... for the preaching of God's word" (Frere and Kennedy 1910, iii, 16). The present pulpit is Victorian, commemorating the last warden of Galway, but it may occupy the same position as its predecessor, at the juncture between the north wall of the chancel and the north transept. If a sermon was included, then the regular Sunday morning worship of Morning Prayer, Litany, and Ante-Communion as a continuous rite would rarely have lasted less than two hours, even longer if there was also a Communion; hence the need for seating.

The tradition of regular sermons in Galway perhaps also helps to explain the preponderance of Galway-born clerics appointed under Elizabeth to bishoprics in the west. Besides Archbishop Bodkin and Warden John Lynch, who later became bishop of Elphin, Stephen Kirwan was appointed bishop of Kilmacduagh (1573-82), and then of Clonfert (1582-1601). His successor there, the Cambridge-educated Rowland Lynch, bishop of both Kilmacduagh (1587-1625) and Clonfert (1602-25), was described as "indeed a right religiouse man for sincere professione \& private life", but he "wanteth coradge freely to preach the Word" (TNA, SP 63/161, ff 118v-19; Canny 1979, 444-5). Finally, there was Nehemiah Donnellan, archbishop of Tuam (1595-1609), who prepared a translation of the New Testament into Irish 
(Ford 1997, 107-8). These Galway-born clergy were all clearly Protestant, a rare thing in the west of Ireland for this period, and they helped to establish Elizabethan Galway as a Protestant centre.

\section{The Decline of “True Religion"}

By 1591, however, Sir Turlough O’Brien wrote “touchinge ye greate declination of $y^{e}$ towne of Galway from their former zeale ... concerning $y^{e}$ profession of $y^{e}$ truth of $y^{e}$ Gospell". The town, he thought, had once been "the paradisse of Ireland in nomber and zeale of professors of the Gospell"; whereas now, through "the negligence of the magistrates" and through Romish flatterers, it was "exceedingly fallen away" and "very few of their men, and not of the cheefest, wilbe seene to frequent" the services (TNA, SP 63/161/52, ff 151r-v). Civic solidarity was breaking down and the townspeople were withdrawing from common prayer.

In part, this was because the Collegiate church no longer had a preaching minister. Critical support for the Collegiate church under Elizabeth was provided by the Galway merchant Francis Martin. In 1586, Martin had asked President Bingham to write in favour of Rowland Lynch, then student of divinity at Cambridge. If Galway had "agoode preacher, beynge so well bent alredye, it wold come in shorte tyme to very good perfection both in town and cuntrye"; but the following year, Lynch had been appointed bishop of Kilmacduagh, just to the west of Galway (TNA, SP 63/122, no. 45). During a visit to Galway in 1595 on a Sunday morning, Lord Deputy Russell and the council "went to church, before whom the bishop of Kilmcdowe [Kilmacduagh] preached both in English and Irish". In the afternoon, Russell's chaplain, Mr Graves, also preached, as he did the following Sunday morning, prompting the mayor to request Russell's 
assistance "for establishing a preacher for the town" (Edwards 2014, 235; Brewer and Bullen 1867-73, iii, 239). In response, William Daniel, educated in Cambridge and recently appointed a fellow of Trinity College Dublin, resigned his fellowship and came to Galway in early 1596, remaining until 1601, when he returned to Dublin to steer the New Testament and then the Irish prayer book through the press before being appointed archbishop of Tuam in 1609 (Ford 1997, 106-11). Daniel was briefly succeeded in Galway by another preaching minister, Abel Walsh, also fellow of Trinity and previously Daniel's student there, but he left in 1602 (Ford 1997, 110).

Gradually, the Reformation in Galway lost ground through the shortage of preaching ministers and of the financial resources to pay them. When Lord Deputy St John visited Connaught in 1611, he concluded that throughout the province, apart from Archbishop Daniel and his aged predecessor, Archbishop Donnellan,

there is indeede noe ministry at all, noe churches standing, \& very fewe places where those that are well affected in religion can assemble; $\& \mathbf{w}^{\text {ch }}$ is worst of all, the levenges left so small as scarcely in the province out of the cheif townes any othe benifice can be founde worth $\mathrm{x}$ "per annum (TNA, SP 63/231, no. 31)

This had been the position for some time; when the Connaught dioceses of Tuam, Elphin, Clonfert, Killala, and Achonry were eventually assessed for First Fruits and Twentieths in 1585-6, none of the benefices was worth as much as $£ 10$ a year, except for the bishoprics themselves, the deanships of Elphin and Clonfert, and the rectories of Athenry and Loughrea. And only the bishoprics of Tuam and Elphin were worth the $£ 30$ minimum seen as necessary to support a graduate preaching minister (Valor beneficiorum, 22-6). 
The regal visitation of the province of Tuam, which followed in 1615, found that in Galway itself the corporation was firmly recusant, and little effort had been made to provide the city's churches with reformed clergy (O'Sullivan 1942, 111; Hardiman 1820, 218; Brewer and Bullen 1867-73, v, 145). The Collegiate church had, in practice, only two of its complement of nine clergy, and one was of dubious reputation and scarcely of good living ("homo lesie fame, et vix probate vite"); he had been promoted by the corporation and elected warden just before the visitors' arrival. The other was a pluralist absentee with livings in various other dioceses ("vagus, undiquaquam cursitans et alias in diversis diocesibus beneficiatus") (O'Flaherty 1846, 214; entry for the College of Galway, Regal Visitation, 1615). In theory, there were, at the time of the visitation, four more clergy with the title of vicar at the Collegiate church, but all five vicars had Irish names and were also vicars choral of Tuam cathedral; two of them also held other livings, no doubt because their livings in Galway and Tuam were worth so little. And whereas the College's income had formerly amounted to $£ 80$ yearly, previous wardens had alienated properties without authority, so reducing its income to $£ 40$ a year. This was barely sufficient to support even one preaching minister. Thus, the visitors concluded, in the same city they live for the more part without divine service and almost without God on earth ("quod in eadem civitate vixissent pro maiore parte sine servitio divino et pene absque deo in terris") (O'Flaherty 1846, 214; Leslie with Crooks 2008, 81, 136, 327, 499, 501-2, 521, 551; British Library, Add. MS 19,836, f. 97 (as cited in Ford 1997, 111).

Across Tudor England, where the authorities had been able to reform the use of sacred space and enforce the provisions of the prayer book in line with the Elizabethan settlement, "the love and due reverence of God's true religion now truly set forth by public authority" had developed promptly enough once the sights and sounds of "idolatry and superstition" had 
been "utterly extinct and destroy[ed]" (Frere and Kennedy 1910, iii, 16, 21, quoting The Elizabethan Injunctions). In Elizabethan Galway, early success had ensued from a more conservative remodelling both of sacred space and of the church's soundscape, combined with a focus on a more popular aspect of prayer-book services, regular sermons. An attenuated form of the traditional sung Latin liturgy, with choristers, organ, and bells, had long competed with the sound of corporate worship according to the English prayer book. The minimalistic remodelling of sacred space had disguised the extent of the theological changes; and the appeal of regular sermons was further enhanced by an imaginative use of language - preaching in Irish, or bilingually, was clearly not unusual. Later, however, the preaching of the Word was only intermittently provided in sermons and homilies, and for some at least "in a tongue not understanded of the people". Once the more novel and dynamic aspects of this local compromise were reduced, the majority of the Galway townsmen drifted back into traditional Catholic worship, which had all along remained freely available outside the town.

\section{Acknowledgements}

This paper was first presented at a conference held at the Johannes a Lasco Bibliothek, Emden, Germany, on the theme "Zwischen Kanzel und Altar: die (neue) Materialität des Spirituellen" in April 2016. I am grateful to the organizers, Professor Dr. Raingard Esser (Rijksuniversiteit Groningen) and Professor Dr. Andrea Strübind (Carl von Ossietzky Universität Oldenburg), for their invitation to present, and also to the participants for their comments on the paper. 


\section{References}

Berry, J.F. [1912] 1989. The story of St. Nicholas' Collegiate church, Galway. Facsimile. Galway.

Booty, J.E., ed. 2009. The Book of Common Prayer 1559: the Elizabethan Prayer Book. Charlottesville: The University of Virginia Press.

Bradshaw, Brendan. 1974. The dissolution of the religious orders in Ireland under Henry VIII. Cambridge: Cambridge University Press.

Brady, Ciaran, ed. 2002. A viceroy's vindication? Sir Henry Sidney's memoir of service in Ireland, 1556-78. Cork: Cork University Press.

Brereton, Sir William. 1844. Travels in Holland, the United Provinces, England, Scotland, and Ireland (1634-5). Chetham Society.

Brewer, J.S., and W. Bullen, eds. 1867-73. Calendar of the Carew manuscripts preserved in the archiepiscopal library at Lambeth, 1515-74 [etc.], 6 vols. London.

Butler, James Goddard, ed. 1786-1801. The Statutes at large passed in the parliaments held in Ireland. 20 vols. Dublin.

Canny, Nicholas. 1976. The Elizabethan conquest of Ireland: a pattern established 1565-76. Hassocks: The Harvester Press.

—— . 1979. "Why the Reformation failed in Ireland: une question mal posée." Journal of Ecclesiastical History 30: 423-50.

Collins, Arthur, ed. 1746. Letters and memorials of state written by Sir Henry Sidney. 2 vols. London: T. Osborne.

Coster, Will, and Andrew Spicer. 2005. "Introduction: the dimensions of sacred space in Reformation Europe." In Sacred space in early modern Europe, edited by Will Coster, and Andrew Spicer, 1-16. Cambridge: Cambridge University Press. 
Digges LaTouche, James J., ed. 1994. The Irish Fiants of the Tudor sovereigns during the reigns of Henry VIII, Edward VI, Philip \& Mary, and Elizabeth I. 4 vols. Dublin: Edmund Burke Publisher.

Edwards, David, ed. 2014. Campaign journals of the Elizabethan Irish wars. Dublin: Irish Manuscripts Commission.

Ellis, Steven G. 1984. "John Bale, bishop of Ossory, 1552-3." Journal of the Butler Society 11 (3): 28.

- - 1990. "Economic Problems of the Church: Why the Reformation Failed in Ireland." Journal of Ecclesiastical History 41: 239-65.

Empey, Adrian, ed. 2009. The proctors' accounts of the parish church of St Werburgh, Dublin, 1481-1627. Dublin: Four Courts Press.

Frere, Walter Howard, and William Paul McClure Kennedy, eds. 1910. Visitation articles and injunctions of the period of the Reformation. 3 vols. London: Longmans.

Ford, Alan. 1995. "The Church of Ireland, 1558-1634: a puritan church?" In As by law established: the Church of Ireland since the Reformation, edited by Alan Ford, James McGuire, and Kenneth Milne, 52-68. Dublin: The Lilliput Press.

-_- 1997. The Protestant Reformation in Ireland, 1590-1641. Dublin: The Four Courts Press.

Gillespie, Raymond, ed. 1996. The proctor's accounts of Peter Lewis 1564-1565. Dublin: Four Courts Press.

- - , ed. 1997a. The first chapter act book of Christ Church Cathedral, Dublin, 1574-1634. Dublin: Four Courts Press.

- - . 1997b. Devoted people: belief and religion in early modern Ireland. Manchester: Manchester University Press.

_-_. 2000. "The shaping of reform, 1558-1625." In Christ Church cathedral Dublin: A History, edited by Kenneth Milne, 174-194. Dublin: Four Courts Press. 
Hardiman, James. 1820. History of the town and county of the town of Galway. Dublin: Beacon Printing.

Haugaard, William P. 1968. Elizabeth and the English Reformation: The Struggle for a Stable Settlement of Religion. Cambridge: Cambridge University Press.

Heal, Felicity. 2003. The Reformation in Britain and Ireland. Oxford: Oxford University Press.

Higgins, Jim, and Susanne Heringklee, ed. 1991. Monuments of St Nicholas' Collegiate church, Galway: a historical, genealogical and archaeological record. Galway: Crow's Rock Press.

Jefferies, Henry A. 2010. The Irish Church and the Tudor Reformations. Dublin: Four Courts Press.

Leask, Harold G. 1936. “The Collegiate Church of St Nicholas, Galway." Journal of the Galway Archaeological and Historical Society 17: 2-23.

Leslie, James B., with D.W.T. Crooks. 2008. Clergy of Tuam, Killala and Achonry: Biographical Succession Lists. Belfast: Ulster Historical Foundation.

Liber Precum Publicarum, seu Ministerij Ecclesiasticae Administrationis Sacramentorum, Aliorumque Rituum \& Ceremoniarum in Ecclesia Anglicana. 1560. London.

Lyttleton, James. 2008. "Anglican church architecture in seventeenthcentury Offaly." Journal of the Royal Society of Antiquaries of Ireland 138: 80-104.

MacCulloch, Diarmuid. 1999. Tudor church militant: Edward VI and the Protestant Reformation. London: Allan Lane the Penguin Press.

_- - 2005. "Putting the English Reformation on the map." Transactions of the Royal Historical Society 15: 75-95. 
MacLysaght, Edward, and H.F. Berry. 1944. "Report on documents relating to the wardenship of Galway." Analecta Hibernica 14: $1-250$.

McDermott, Jennifer Rae. 2012. “'The Melody of Heaven': Sermonizing the Open Ear in Early Modern Europe." Religion and the Senses in Early Modern Europe, edited by Wietse de Boer, and Christine Goettler, 177-198. Leiden: Brill.

McNeill, Charles. 1992. "Accounts of sums realised by sales of chattels of some suppressed Irish monasteries." Journal of the Royal Society of Antiquaries of Ireland 52: 11-37.

Milne, Kenneth, ed. 2000. Christ Church Cathedral, Dublin, a History. Dublin: Four Courts Press.

Morrin, James, ed. 1862. Calendar of the patent and close rolls of chancery in Ireland from the 18th to the 45th of Queen Elizabeth. Dublin: HMSO.

Murray, James. 2009. Enforcing the English Reformation in Ireland. Clerical Resistance and Political Conflict in the Diocese of Dublin, 1534-1590. Cambridge: Cambridge University Press.

Nicholls, K.W., ed. 1970. "Visitations of the Dioceses of Clonfert, Tuam and Kilmacduagh c.1565-67." Analecta Hibernica 26: 151-7.

O'Flaherty, Roderic. 1846. A chorographical description of West or Hiar, Connaught. Written in AD 1684. Dublin: Irish Archaeological Society.

O'Sullivan, Mary D. 1942. Old Galway. Cambridge: W. Heffer and Sons Limited.

Parke, Thomas, ed. 1810. “The vocacyon of Johan Bale to the bishoprick of Ossorie in Ireland." Harleian Miscellany 6: 437-464.

Rigg, J.M., ed. 1916, 1926. Calendar of state papers relating to English affairs, preserved principally at Rome. 2 vols. London: HMSO. 
Robinson, Hastings, ed. 1842. The Zurich Letters or, the correspondence of several English bishops and others, with some of the Helvetian Reformers during the reign of Queen Elizabeth, 1558-1579. Cambridge: Parker Society.

Ronan, Myles V. 1930. The Reformation in Ireland under Elizabeth, 15581580. Dublin: Longmans, Green and Company.

Smith, Mark M., ed. 2004. Hearing History. A Reader. Athens: University of Georgia Press.

The National Archives, SP 63, State Papers, Ireland, Elizabeth

Trinity College Dublin, MS 581

Valor beneficiorum ecclesiasticorum in Hibernia: or the first fruits of all the ecclesiastical benefices in the kingdom of Ireland, as taxed in the king's book. 1741. Dublin: Edward Exshaw Bookseller.

White, N.B., ed. 1941. "The annals of Dudley Loftus." Analecta Hibernica 10: 223-38.

Whiting, Robert. 2010. The Reformation of the English parish church. Cambridge: Cambridge University Press.

Yates, Nigel. 2008. Liturgical space: Christian Worship and Church Buildings in Western Europe 1500-2000. Aldershot: Ashgate Publishing Limited. 